\title{
CEO Compensation Trends in the Republic of Serbia in the Context of EU Integration
}

\author{
Ivana Marinović Matović \\ Addiko BankAD Belgrade, Serbia, ivana.m.matovic@gmail.com
}

\begin{abstract}
CEO compensations are an effective instrument for adjusting the interests of managers and equity owners, so that full engagement and commitment can only be expected of managers who are sufficiently motivated. Among other things, sufficient motivation is achieved by the use of adequate CEO compensations. This paper analyzes applied models of CEO compensation, and their levels, in the Republic of Serbia and EU member countries. Comparison of CEO compensation in the Republic of Serbia and EU countries will enable the positioning of the Republic of Serbia in the context of EU integration; as well as enable Serbian business organizations to track trends that are current, and structure their CEO compensations to meet managers' expectations in terms of attractiveness, and equity owners in terms of cost efficiency. The paper will try to determine the existing differences in CEO compensation levels, conditioned by the degree of economic development of the observed countries. The paper will analyze the factors that directly or indirectly affect the level of CEO compensation. It will try to determine which components of CEO compensation are mostly used in business organizations from the EU, and compare the results with business organizations from the Republic of Serbia in order to improve existing practice. As CEO compensations are still underdeveloped area in the Republic of Serbia, the contribution of the paper is expected to be significant, for Serbian business organizations that operate, or plan to operate, on the international market, and allow their managers to work in EU countries. Strategy and policy of CEO compensation is a very sensitive area, so the focus of the paper is on identifying existing differences that could be used in terms of convergence of the CEO compensation practice in the Republic of Serbia to the one that is present in the more advanced EU countries, in the context of EU integration.
\end{abstract}

KEYWORDS: CEO compensation, Republic of Serbia, EU integration, compensation trends

\section{Introduction}

CEO compensation models, which significantly influence the desired performance of managers, are of great interest to the scientific and professional public. The paper analyzes applied models of CEO compensations, and their levels, in the case of selected EU countries and the Republic of Serbia. In this regard, the applied models of CEO compensations are considered, as well as their basic components, the comparison of the observed sample of countries is carried out, as well as the adequate modeling of CEO compensations in order to achieve and maintain the competitive advantage in the global market. According to the conducted research (Kotnik et al. 2017) EU managers (especially in the UK, Germany and France) make the highest compensations. The EU countries also have the highest ratio between CEO compensations and compensation of other employees (Kotnik et al. 2017). Within the EU, the highest level of compensation is earned by managers in the United Kingdom, Germany and France (Equilar 2016). The degree of economic development, as well as many other factors, directly or indirectly affect the level of CEO compensation. Comparison of CEO compensation in the Republic of Serbia and EU countries will enable the positioning of the Republic of Serbia in the context of EU integration; as well as enable Serbian business organizations to track trends that are current, and structure their CEO compensations to meet managers' expectations in terms of attractiveness, and equity owners in terms of cost efficiency.

\section{CEO compensation trends and developments}

The CEO compensation strategy implies the development and application of rewarding policies, processes and practices over a longer period of time, in order to achieve business goals (Amstrong \& Murlis, 2014). The CEO compensation strategy enables achievement of the organizational business performances, and accordingly it needs to be developed and firmly linked to the planned business outcome and human resource management strategy. In order to achieve and maintain competitive 
advantage, each business organization develops an adequate CEO compensation model that supports the business strategy realization.

Size of business organization, organization growth opportunity, risk, capital structure, ownership structure and the age of managers have the most significant influence on CEO compensation models (Polak et al., 2014). The size of a business organization is of great importance for the level of CEO compensation, due to the demands for the management of the highest quality and significant business skills and experience. Highly qualified and experienced managers at the highest management positions require significant and custom-made compensation models, due to the nature and responsibility of the work they perform. The capital structure is important in determining salary, as the basic component of the CEO compensation models, which determines the demand of managers for optimal capital structure. The ownership structure of the business organization also has an impact on the salary level within the compensation model. Business organizations that are in majority state ownership generally have more modest CEO compensations, in contrast to organizations in majority private ownership. The managers' age also influences the level and applied the model of CEO compensation. Older managers are focused on long-term goals, while younger managers place emphasis on short-term goals.

The applied CEO compensation model should be competitive in comparison with related business organizations. The CEO compensation model should also be attractive enough and tempting, which is achieved by an adequate combination of material and immaterial, fixed and variable components of the compensation model (Marinović-Matović \& Marinović 2011). The fixed component of the compensation model provides security and the required level of living standard to managers. The variable component of the compensation model motivates managers to achieve desired business performances.

The structure and scope of CEO compensation models represent the choice of each business organization. A fixed component of the compensation model contains the basic salary and benefits, while the variable component includes short-term and long-term incentives (Buble \& Bakotić 2013). Long-term incentives, as an element of total CEO compensation, have been designed with the aim of achieving long-term goals. The amount of incentives depends on the achievement of business organization's goals. The manager can earn a significant reward, in case of achieving or exceeding the given business performance. The payment of this compensation component is based on the value achieved for shareholders or the financial performances of a particular organizational unit. Forms of long-term incentives are different; most are based on the involvement of managers in the ownership of a business organization (Marinović Matović \& Marinović 2011).

In order to change the location of top managers, it is necessary to apply a unique reward strategy and the structure of CEO compensations. The CEO compensation models in dislocated parts of a business organization most often imply an identical reward strategy and applied models that are present in the home country. Determining the size and the structure of the CEO compensation is within the scope of the supervisory board, remuneration committee and rewarding advisers. The supervisory board oversees the work of the board of directors, directs and controls the remuneration policy, and decides on CEO compensation models for the highest management levels. The remuneration committee provides support and assistance to the supervisory board in determining the CEO compensation model, while the rewarding advisor defines competitive and responsible compensation models for the highest management structure (Galetić 2012).

\section{CEO compensation landscape in EU and the Republic of Serbia}

The most important components of the CEO compensation models in the EU countries are benefits, perquisites and long-term incentives (Mercer 2013). In the EU countries, short-term material incentives are equally important. The salary increase in 2012 was realized in a significant amount with managers in EU contries, compared to the managers of other European countries (Mercer 2013). Business organizations in Europe centralized decision-making on CEO compensations through management teams. 
The interest of the scientific public in most EU countries has been focused on CEO compensation models for years, emphasizing the need to increase the control of these models, which implied new legislation. A few years after the global economic crisis outbreak, in 2012, business organizations from the EU countries conducted salary freezing, including primarily managers' salaries (Mercer 2013). Opinion on the level and structure of CEO compensations has led to new tax regulations in certain EU countries, aimed at taxing higher levels of material rewards. During 2012, the financial sector enabled the payment of incentives, postponed in the previous years. Deferred incentives payment has been introduced in most EU countries since the beginning of 2011, due to new EU regulations regarding the capital level for credit and investment institutions, which covers $43 \%$ of business organizations. The share of managers who did not exercise the right to long-term incentives in the total number of managers dropped from 26\% in 2011 to 22\% in 2012 (Haygroup 2013). Longterm incentives in business organizations in EU countries have not changed since 2012. Since 2013, EU countries have paid attention to the public data on the amount and structure of the CEO compensation models. Business organizations of EU countries have accepted the awareness of compensation risks and included them in the process of managing other strategic and operational risks.

Models of CEO compensations are similar in the largest business organizations of the EU countries. The data show that $56 \%$ of the total CEO compensation in Europe make incentives, while the remaining 44\% are salaries (Haygroup 2013). Long-term incentives are becoming more and more one of the most important components of the compensation model in EU. Compensation at the highest management levels, including short-term incentives, amounts to around 1.3-1.4 million EUR gross, annually. The amount of long-term incentives, in the form of stock options, is at the level of around 76,500 EUR. During 2013, the average amount of CEO compensation in business organizations with over 100,000 employees amounted to 1.35 million EUR gross per year. This amount includes 660,000 EUR of basic salary and 690,000 EUR of short-term incentives (Pedersen \& Partners 2013). The global survey, conducted by Pedersen \& Partners in 2013, included a sample of 1,700 managers from 17 national economies and 330 business organizations (Pedersen \& Partners 2013). This survey provided information on the basic salary within the CEO compensation model, which was increased by $5.5 \%$ in relation to 2012 . The total amount of CEO compensation was increased by $3.4 \%$ (including short-term incentives). EU countries are characterized by the highest level of CEO compensation, closely related to the size of a business organization. The survey provided information that CEO compensations were increased by an average of $4-5 \%$ in EU countries, and 7-10\% on average in developing economies. The average amount of CEO compensation in major EU business organizations during 2013 and 2014 amounted to EUR 1.4 million annually. This amount of compensation was increased by $3.5 \%$ compared to the previous business year, and the CEO compensation included the basic salary in the amount of 681.000 EUR and short-term incentives in the amount of 719.000 EUR gross (Pedersen \& Partners 2013).

Table 1. Average CEO compensation at annual level (gross) in 2013

\begin{tabular}{|c|c|}
\hline Country & $\begin{array}{c}\text { Average CEO compensation } \\
\text { (EUR) }\end{array}$ \\
\hline United Kingdom & 220.200 \\
\hline Germany & 215.000 \\
\hline French Republic & 181.400 \\
\hline The Republic of Serbia & 72.800 \\
\hline \multicolumn{2}{|c|}{ Source Pedersen \& Partners 2013}
\end{tabular}

Source: Pedersen \& Partners 2013

Table 1 shows the average values of CEO compensations in selected EU countries for 2013. The CEO compensations include basic salary and short-term material incentives (total gross cash compensation). The data relate to business organizations with 200-300 employees. According to the survey, the forecast of salary increase in 2016 was as follows: Germany 3.0\%, United Kingdom: $3.0 \%$, French Republic: $2.5 \%$ and the Republic of Serbia 5.5\% (Mercer 2014). 
The trend of increase in CEO compensations is present in business organizations in United Kingdom, where in 2011 , as many as $79 \%$ of managers received compensations higher than it was planned. The trend of compensation growth continued in 2012.

Table 2. Average CEO compensation in the United Kingdom in 2013

\begin{tabular}{|c|c|c|c|c|}
\hline $\begin{array}{c}\text { Number of } \\
\text { employees }\end{array}$ & $\begin{array}{c}\text { Basic } \\
\text { salary } \\
\text { (EUR) }\end{array}$ & $\begin{array}{c}\text { Cash } \\
\text { incentives } \\
\text { (EUR) }\end{array}$ & $\begin{array}{c}\text { Total } \\
\text { material } \\
\text { compensation } \\
\text { (EUR) }\end{array}$ & $\begin{array}{c}\text { Incentives in stock } \\
\text { options (EUR) }\end{array}$ \\
\hline Over 100.000 & 747.200 & 544.100 & 1.291 .300 & 31.200 \\
\hline 20.000 to 50.000 & 515.700 & 258.100 & 773.800 & Salary increase \\
\cline { 4 - 5 } & &
\end{tabular}

Source: Pedersen \& Partners 2013

Table 2 shows the average CEO compensations in the UK in 2013. The average CEO compensation includes basic salary, cash incentives, total material compensation, as well as stock options and salary increases. The data are divided according to the business organization size, with over 100,000 employees and those from 20,000 to 50,000 employees. We can compare this information with the amount of compensation for other UK employees. The Hudson Annual Compensation Review for 2015 shows the range of compensation on annual basis in certain UK cities (Hudson 2015). The compensation includes the basic salary, pension contributions, incentives and stock options. According to data from Hudson, the lawyers' annual compensation in London for 2015 ranges to a maximum of 67,500 GBP. In the UK public business organizations operating in cities such as Birmingham, Bristol and Manchester, the lawyers' annual compensation ranges from 39,000 GBP to a maximum of 44,000 GBP, while in small and medium-sized business organizations, the compensation amounts to a maximum of 31,000 GBP (Hudson, 2015).

In business organizations in Germany, during 2007 and 2008, average CEO compensations amounted to 127,113 EUR and 120,581 EUR (Koch \& Stadtmann 2013). Short-term incentives (variable component of compensation), which were $47 \%$ and $49 \%$ of the total compensation, was singled out as the most important component of CEO compensation, followed by a fixed component (salary), with a share of $33 \%$ and $29 \%$ of the total compensation. The highest compensation amounted to 682,438 EUR, the average compensation amount was 125,492 EUR, while the lowest compensation amounted to 21,228 EUR (Koch \& Stadtmann 2013).

After the observed period, starting from 2008 until 2011, the impact of the global economic crisis has also been intense in the field of CEO compensations and compensations of high-qualificated experts within the German chemical industry. In 2009, Germany was heavily affected by the economic crisis, which led to a 5\% reduction in GDP (Grund \& Walter 2013). The incentive payments significantly decreased during the crisis, and the repeated economic growth from 2011 resulted in a CEO compensations increase to amounts higher than in pre-crisis period.

During the economic crisis, there was a noticeable decline in CEO compensations within the German chemical industry. Although the German chemical industry accounts for $15 \%$ of total German exports and Germany is the world's largest exporter of chemical products, the economic crisis negatively influenced this sector, which was manifested by a $15 \%$ drop in sales. The basic component of CEO compensations was a fixed salary (81\%), while the incentives amounted to $15 \%$, and the stock options were $4 \%$ of the total compensation (Grund \& Walter 2013). The reduction in wages was felt by only $9 \%$ of employees in this sector, whose wage declined from 2008 to 2011 , while 7\% of managers felt the reduction of their compensation packages.

Table 3 presents the average CEO compensations in Germany for 2013. It includes the amount of basic salary, cash incentives, total material compensation, as well as stock options and salary increases. Data includes business organizations with over 100,000 employees and those employing between 20,000 and 50,000 workers. The basic salary in Germany is lower than the basic salary in the UK, while the amount of cash incentives is higher in Germany than in the UK. The total material compensation was higher in Germany than in the UK. 
Table 3. Average CEO compensation in Germany in 2013

\begin{tabular}{|c|c|c|c|c|}
\hline $\begin{array}{c}\text { Number of } \\
\text { employees }\end{array}$ & $\begin{array}{c}\text { Basic } \\
\text { salary } \\
\text { (EUR) }\end{array}$ & $\begin{array}{c}\text { Cash } \\
\text { incentives } \\
\text { (EUR) }\end{array}$ & $\begin{array}{c}\text { Total } \\
\text { material } \\
\text { compensation } \\
\text { (EUR) }\end{array}$ & $\begin{array}{c}\text { Incentives in stock } \\
\text { options (EUR) }\end{array}$ \\
\hline Over 100.000 & 701.100 & 740.000 & 1.441 .100 & 95.000 \\
\hline 20.000 to 50.000 & 495.000 & 319.000 & 814.000 & Salary increase \\
\cline { 4 - 5 } & &
\end{tabular}

Source: Pedersen \& Partners 2013

The global economic crisis has caused some changes in the regulation of CEO compensations in the French Republic. In 2012, the French government imposed limitations on compensation in stateowned business organizations and increased control over the stock options as long-term incentives. Taking into account the level of CEO compensation, the French Republic introduced a tax rate of income of $75 \%$. French business organizations reimburse employees with more than 35 hours per week in the form of contributions, as well as $50 \%$ of the transport costs, through salary or separately from salary. In the French Republic, starting from 01.01.2018, the minimum salary per hour is 9.88 EUR gross, which is a significant increase compared to 9.43 EUR in 2013. As shown in Table 4 in the same observed period, the monthly minimum salary increased to 1.498,47 EUR gross in 2018, based on 35 working hours per week, compared to EUR 1,430.22 in 2013 (JDN 2018).

Table 4. Minimum salary in business organizations of the French Republic in 2013-2018

\begin{tabular}{|l|c|c|c|}
\hline & $\begin{array}{c}\text { Monthly } \\
\text { minimum } \\
\text { salary gross } \\
\text { (EUR) }\end{array}$ & $\begin{array}{c}\text { Minimum } \\
\text { salary per hour } \\
\text { gross (EUR) }\end{array}$ & $\begin{array}{c}\text { Monthly } \\
\text { minimum } \\
\text { salary net } \\
\text { (EUR) }\end{array}$ \\
\hline 1.1 .2013$. & $1.430,22$ & 9,43 & $1.120,43$ \\
\hline 1.1 .2014$. & $1.445,38$ & 9,53 & $1.128,70$ \\
\hline 1.1 .2015$. & $1.457,52$ & 9,61 & $1.135,99$ \\
\hline 1.1 .2016$. & $1.466,62$ & 9,67 & $1.143,72$ \\
\hline 1.1 .2017$. & $1.480,27$ & 9,76 & $1.153,00$ \\
\hline 1.1 .2018$. & $1.498,47$ & 9,88 & $1.173,00$ \\
\hline
\end{tabular}

Source: JDN (April 13, 2018)

The business organizations of the French Republic since 2015 have been focused on retaining of key employees and aligning salaries with collective agreements. French multinational business organizations have different compensatory policies for mature markets and emerging markets. Differences are reflected in defining salaries according to the position in the business organization, in strong relationship between compensation and achieved performances, in the process of career development.

A survey on the CEO compensation structure in the Republic of Serbia included the average compensation analysis, and was conducted by the Delegation of the German Economy in Serbia and the German-Serbian Economic Association, in cooperation with Kienbaum Management Consultants in 2012 (Vučković 2012). The survey included 21 business organizations in private ownership of domestic and foreign capital, and a total of 1,012 employees working in 25 positions (Vučković 2012). The research involved: the mechanical sector (24\%), the financial sector (18\%), the electronic sector $(14 \%)$, chemical and pharmaceutical sector $(14 \%)$, metal sector $(10 \%)$, food sector with tobacco industry $(10 \%)$ and transport and logistics sector $(10 \%)$.

CEO compensation, according to this research, is characterized by significant amounts. The gross compensation of general managers ranges from 2,500,000 to $13,500,000 \mathrm{RSD}$, the leading managers from 450,000 to 8,500,000 RSD, the department managers from 250,000 to 3,600,000 RSD. Observed at the average level and by certain executive positions, the average amount of CEO compensation (gross) is: 5,399,000 RSD (general manager), 3,122,000 RSD (sales manager), 
2,061,000 RSD (marketing manager), 2,313,000 RSD (key account manager), 2,232,000 RSD (financial manager), 1,620,000 RSD (control manager), 1,835,000 RSD (human resource manager), 1,762,000 RSD (transport and logistics manager), 1,538,000 RSD (facility manager), 1,477,000 RSD (development manager) (Vučković, 2012).

The results of the research have shown that the variable components of CEO compensation represent a very small percentage of total compensation. The percentage of participation of variable components in total manager compensation is only 5\% (Vučković 2012). Observed by position, the characteristics of the CEO compensation models in the Republic of Serbia is that the general managers are not in the first position by the percentage of variable components participation in the total compensation. Key account managers receive the highest percentage of variable components (25\%), followed by general managers (8\%), and other leading managers (7\%) (Vučković 2012).

\section{A comparison of CEO compensation between the EU and the Republic of Serbia}

Characteristic of the observed national economies of EU countries is the introduction of control measures for CEO compensations, due to their high amounts, large incentive payments, and in order to reduce the disproportionate relationship in CEO compensations. United Kingdom limited amounts of CEO compensations, while a better control of compensation and regulation of the financial market was introduced in Germany. The French Republic has introduced stricter executive salary and incentive control, and is characterized by a reduction in CEO compensation for $17.6 \%$. In the Republic of Serbia, no measures were taken regarding CEO compensation control, nor was their reduction implemented, which was expected considering the structure and height of executive compansations. Looking at the salaries' increase in the observed national economies, the largest increase was recorded in the United Kingdom, where $79 \%$ of managers received a salary higher than the planned amount in 2011. In Germany, this percentage was slightly lower and amounted to $71 \%$. United Kingdom is characterized by high levels of CEO compensation and a high salary growth during 2011 and 2012. In Germany, in 2011 and 2012, the executive salaries increased by 4.2\%. The annual amounts of CEO compensations in the UK are extremely high, while in Germany they are moderately high. The survey showed that the executive salaries in Germany were higher than the executive salaries in French business organizations. French managers, compared to managers in the Republic of Serbia, have much higher salaries, partly because of the fact that Serbian managers are engaged in much smaller business organizations unlike those of the French. Data on changes in the level of CEO compensations in the Republic of Serbia are not available, they have not been the subject of research so far.

Observing the business organizations with over 100,000 employees, the research has shown that the CEO salaries in the UK are higher than in Germany. However, the total material CEO compensation was higher in German business organizations than in the UK. German managers made greater compensations in total thanks to a significant share of cash incentives, which was even $106 \%$ of German salaries, while in the United kingdom, the manager could receive $73 \%$ of salary in cash incentives. Also, long-term incentives in stock options were paid in a significantly higher amount to managers in Germany (95,000 EUR), compared to managers in the United Kingdom (31,200 EUR). The same trend was recorded in business organizations with 20-50,000 employees. The incentives participation in total CEO compensation in the Republic of Serbia is negligible. Also, while in the EU countries there is a noticeable trend of increasing participation of long-term incentives in total CEO compensation, this component is not present in the CEO compensation strategy in the Republic of Serbia.

The average CEO compensation in 2013 was the highest in the UK, and the smallest in the Republic of Serbia. If we compare the executive salaries and other employees salaries, one can say that the biggest difference is noticeable in the UK. Research has shown that managers of business organization in the UK have an average annual salary of 4,946 million GBP, compared to the average salary of other employees, which is 27,195 GBP annual. Due to such large differences, it was necessary to introduce a number of restrictive and control measures of CEO compensations. 
During 2014 and 2015, many European business organizations introduced salary harmonization programs with a collective agreement, improved job evaluation, and a reduction in CEO compensations. The best-paid EU managers are Swiss managers, while in second-place are UK managers (Pedersen \& Partners, 2013). Executive salaries in developed economies are significantly higher than in the Republic of Serbia. Globally, when we compare the CEO compensations between the United States and Europe, it can be concluded that US managers receive several times higher amounts.

Investigating CEO compensation in Europe, it is concluded that salaries and total compensation largely depend on the business organization size, as well as on the capital structure, ownership structure, possibility for business organization growth, GDP level, managers' age, and many other factors. Large business organizations, operating on the global market and gaining a competitive advantage, earn higher profits than other business organizations. Also, national economies that are important exporters, whose business organizations operate on the global market, gain additional financial capacity and additional financial gain, resulting in increased CEO compensations. It can therefore be concluded that managers in the UK, Germany and the French Republic are rewarded with higher compensations than managers in the Republic of Serbia, which is evident from the conducted comparative research.

\section{Conclusion}

In recent years the subject of public interest has been oversized CEO compensation and its disproportion compared to other employees' salaries. Managers are the most important asset of each business organization and it is necessary to achieve their high motivation for accomplishing the business goals. This can be achieved if CEO compensations are closely related to the target performances of a business organization. Business organizations that want to achieve a defined strategy and a competitive advantage in the global market must engage managers of appropriate skills, and enable them to continuously progress and develop their career. By modeling CEO compensations, a business organization clearly percieves the results of a managers' motivation, and gets the answer to a question - whether the compensation is critical for the results of top managers.

Strategic goals and business activities should be harmonized, and a business organization should include all the necessary incentives and benefits to attract and retain top-level managers. The CEO compensation package offered by the business organization must be adequately planned and created according to the managers' needs, thereby achieving a better productivity of their work. Managers also need to be provided with the adequate compensation model, which will improve their performances in achieving the set goals. This paper analyzes applied models of CEO compensation, and their levels, in the Republic of Serbia and EU member countries. The survey covered EU countries, especially United Kingdom, Germany, the French Republic, and the Republic of Serbia. The selected EU countries have the highest amount of overall CEO compensation, and also the highest ratio between executive compensations and compensation of other employees. Research has shown the large ranges of CEO salaries in those countries. The global economic crisis has greatly influenced the level of CEO compensations across Europe, which has led to government adjustments of the observed countries and to the limitation of CEO compensations. The research has confirmed that there are large and disproportionate differences in the level of CEO compensations, conditioned by the degree of economic development of the observed national economies, as well as many other factors that directly or indirectly affect the level of CEO compensation (size of business organization, managers' age, capital structure, ownership structure, etc.). Also, the research has confirmed that some of the CEO compensation components, present in developed EU economies, have negligible participation in the Republic of Serbia. These are short-term and long-term incentives. While shortterm incentives (although negligible) are still present in CEO compensation models in the Republic of Serbia, long-term incentives are not part of the executive reward strategy in Serbia, in contrast to the trend present in developed EU economies. Comparison of CEO compensation in the Republic of Serbia and EU countries enabled the positioning of the Republic of Serbia in the context of EU integration; and enabled Serbian business organizations to track trends that are current, and structure 
their CEO compensations to meet managers' expectations in terms of attractiveness, and equity owners in terms of cost efficiency. CEO compensations are still underdeveloped area in the Republic of Serbia, so that Serbian business organizations that operate, or plan to operate, on the international market, should apply CEO compensation models and practices, present in EU countries. Identified existing differences in strategy and policy of CEO compensation in EU countries and the Republic of Serbia should improve CEO compensation practice in the Republic of Serbia, to the one that is present in the more advanced EU countries, in the context of EU integration.

\section{References}

Amstrong, M., Murlis, H. 2004. Reward Management. London: Kogan Page.

Buble, M., Bakotić, D. 2013. Kompenzacijski menadžment. Split: Ekonomski fakultet Split.

Compensation planning for 2015 EMEA Forecasts and Trends. 2014. Marsh\&McLennan Companies, 20. October 2014, downloaded from: http://www.mercer.com/content/dam/mercer/attachments/global/webcasts/mercer-compensationplanning-2015-emea-forecasts-and-trends.pdf, access 22.04.2018.

Equilar (August 17, 2016). How CEO Pay Differs Around the Globe. Retrieved from: http://www.equilar.com/pressreleases/53-how-ceo-pay-differs-around-the-globe.html, access 07.06.2018.

Galetić, L. 2012. Izabrane teme iz kompenzacijskog menadžmenta. Zagreb: Ekonomski fakultet Zagreb.

Grund, C., Walter, T. 2013. "Management Compensation and the Economic Crisis: Longitudinal Evidence from the German Chemical Sector.” IZA Discussion Paper No. 7435, 1-35.

Haygroup. 2013. Top-executive compensation in Europe in 2012. Retrieved from: https://www.haygroup.com/downloads/uk/Top-executive-compensation-in-Europe-2012.pdf.

Hudson. 2015. Hudson Salary Guides $2015 . \quad$ Retrieved from http://cdn.hudson.com/Portals/UK/documents/SalarySurveys/Legal-UK-Salary-Tables-2015.pdf.

JDN. April 13, 2018. Smic 2018: montant mensuel et taux horaire, retrieved from: https://www.journaldunet.fr/management/guide-du-management/1071810-smic-2018-montant-mensuel-et-tauxhoraire/.

Koch, R., Stadtmann, G. 2013. "Determinants of Supervisory Board Compensation in Germany." International Journal of Economics and Management Engineering (IJEME), Vol. 3 Iss. 2, 56-67.

Kotnik, P., Sakins, M.E., Slavec, A., Gudiraš, D. 2017. "Executive compensation in Europe: Realized gains from stockbased pay." ISIGrowth GA, No. 649186.

Marinović-Matović, I., Marinović, M. 2011. "Sistem motivisanja menadžera u funkciji efikasnog upravljanja." BIZinfo anali, 3/2011, 47-56.

Mercer. 2013. Compensation and benefit trends in Europe. Retrieved from https:/www.mercer.com/content/dam/mercer/attachments/global/Talent/human-capitalagenda/Anthology\%202012/2013-compensation-and-benefit-trends-in-europe-2012-mercer.pdf

Mercer. 2014. Compensation planning for $2015 . \quad$ Retrieved from http://www.mercer.com/content/dam/mercer/attachments/global/webcasts/mercer-compensation-planning-2015emea-forecasts-and-trends.pdf

Pedersen \& Partners. 2013. Compensation in World's Largest Corporations Increased by 5.5\%. Retrieved from https://www.pedersenandpartners.com/news/2013/10092013-1441/compensation-world\%E2\%80\%99s-largestcorporations-increases-55.

Polak, M., Bosna, J., Miletić, J. 2014. Pregled strukture i čimbenika menadžerskih kompenzacija, Privredna kretanja $i$ ekonomska politika, Vol. 23. No. 2. (135), 24-35.

Vučković, M. 2012. Plate direktora u privatnim firmama jedan prema otprilike. Biznis\&Finansije, retrieved from: $\mathrm{http} / /$ bif.rs/2012/12/plate-direktora-u-privatnim-firmama-jedan-prema-otprilike/. 